Student Success

ISSN: 2205-0795

Volume 9, Issue 4, pp. 53-62

December 2018

\title{
Exploring online interaction and online learner participation in an online science subject through the lens of the interaction equivalence theorem
}

\author{
Johanna Nieuwoudt
}

Southern Cross University, Gold Coast, Australia

\begin{abstract}
While researchers agree that student participation is key to learning, it seems that the issue of interaction in online learning is not yet resolved. The current study investigated students' online interaction and online learner participation in an online enabling science subject and compared this with their final grades. The data were analysed through the lens of Anderson's (2003) interaction equivalence theorem. The findings from the current study provide support for the interaction equivalence theorem. Studentteacher interaction and student-content interaction were evident, but not student-student interaction. Significant relationships were found between student success and online learner participation, but not online interaction. Generalisations are limited by a small sample size and online interaction and participation was measured in terms of quantity rather than quality. Still, following the interaction equivalence theorem, it appears that students can have a satisfying and meaningful learning experience despite not having student-student interaction.
\end{abstract}

Please cite this article as:

Nieuwoudt, J. (2018). Exploring online interaction and online learner participation in an online science subject through the lens of the interaction equivalence theorem. Student Success, 9(4), 53-62. doi: 10.5204/ssj.v9i4.520

This article has been peer reviewed and accepted for publication in Student Success. Please see the Editorial Policies under the 'About' section of the Journal website for further information.

Student Success: A journal exploring the experiences of students in tertiary education

(c) (i) This work is licensed under a Creative Commons Attribution 4.0 International Licence. As an open access journal, articles are free to use, with proper attribution, in educational and other non-commercial settings. ISSN: 2205-0795 


\section{Introduction}

Many colleges and universities offer degree programs and courses via distance education, making it possible for students to access higher education without physically attending classes (Butner, Smith, \& Murray, 1999). Distance education has evolved through five generations as a result of the development of new technology (Taylor, 2001). The 'distance' in distance education is not as relevant anymore, as new technologies have the potential to remove distance by providing flexibility (Aoki, 2012). It is now possible for students to attend virtual classrooms and participate in discussion forums without leaving their homes. Because of the rapid development of technology, 'distance' education has been replaced by 'online' education. Online learning is becoming increasingly popular (Kahu, Stephens, Leach, \& Zepke, 2013) and is vital in providing students from regional areas access to higher education (National Centre for Student Equity in Higher Education, 2017).

While online education allows more students to study at university, not all students succeed in their studies. Attrition rates are higher for online students compared to on-campus students (National Centre for Student Equity in Higher Education, 2017; Stone, 2017). Furthermore, the rate of attrition approaches $50 \%$ in enabling programs (Hodges et al., 2013; Pitman et al., 2016). It is thus essential to improve student success (Yorke, 2006) in order to decrease attrition rates in enabling programs. "It has become increasingly clear that 'success' means helping all students to become more engaged and more effective learners in higher education, thus improving their academic outcomes" (Thomas, 2012, p. 10). Student engagement is a key factor in student success in higher education (Nelson, Clark, Stoodley, \& Creagh, 2014; Thomas, 2012). Student engagement is multifaceted (Krause \& Coates, 2008) and is "a complex business" (Zepke, 2013, p. 11). Student engagement involves not only academic activities, but also non-academic activities that would contribute to high quality learning (Australian Council for Educational Research, 2008). Student engagement comprises of "motivated behaviour that can be indexed by the kinds of cognitive strategies students choose to use... and by their willingness to persist with difficult tasks by regulating their own learning behaviour" (Chapman, 2003, p. 1). A better understanding of students' learning behaviour in an online subject may lead to increased student success.

Research indicates that participation is central to learning (Wenger, 1998) and is related to interaction and a sense of community in online learning (Delahunty, Verenika, \& Jones, 2014). Online interaction often occurs in synchronous chatrooms, asynchronous discussion forums, and via email and can be seen as engagement in a meaningful discussion, with online interaction being the equivalent of face-to-face tutorial discussions (Delahunty et al., 2014). Online learning communities are formed through online learner participation and are comprised of the teacher and students from diverse geographical locations and sociocultural backgrounds (Goertzen \& Kristjánsson, 2007). It is thought that successful interaction depends on cooperation and a good relationship between students and the teacher (Goertzen \& Kristjánsson, 2007). However, interaction can be forced when students' contributions in discussion forums are assessed. Hrastinski (2008) defined online learner participation as "a complex process comprising doing, communicating, thinking, feeling and belonging, which occurs both online and offline" (p. 1761). Online learner participation varies from merely accessing the online learning system to taking part in rewarding discussions (Hrastinski, 2008). The individuals in the learning community share the common goal of learning (Goertzen \& Kristjánsson, 2007). It is thus not unexpected that there appears to be a positive relationship between being part of an online community and learning (Sadera, Robertson, 
Song, \& Midon, 2009). A sense of community can decrease feelings of isolation that is often experienced by online students. A sense of community can also increase retention rates (Liu, Magjuka, Bonk, \& Lee, 2007; Owens, Hardcastle, \& Richardson, 2009). It is generally accepted that students need to belong to an interactive community of learners to be academically successful in online learning (Garrison \& Cleveland-Innes, 2005). Nonetheless, this may not be true for all students.

Anderson (2003) developed the interaction equivalency theorem to address the value of interaction in learning. Interaction comprises of student-student, student-teacher, and studentcontent interaction. If one of the forms of interaction is at a high level, then the other two forms of interaction can be at lower levels or even eliminated without having detrimental effects on learning (Anderson, 2003). Thus, a high level of engagement in one of the three forms of interaction will allow students to engage in deep and meaningful learning, whilst having a satisfying learning experience. The student is central to interaction. Studentstudent interaction is looking at how the student is interacting with other individual students or in small groups. Student-teacher interaction refers to interaction between the student and the teacher, with the interaction being synchronous or asynchronous. Studentcontent interaction is about interaction with the content. This includes using study guides, reading texts, watching videos, searching for information, and completing assessments (Bernard et al., 2009). The student should ideally be personally active and engaged instead of simply observing other active participants (Anderson, 2003).

The purpose of this research is to investigate the role online interaction and learner participation may play in student success in an online enabling science subject from a regional university. This research was guided by Anderson's interaction equivalency theorem.
This research aimed to: (a) investigate the forms of interaction students were engaged in, (b) determine if students had a deep and meaningful learning experience, and (c) determine if students had a satisfying learning experience.

\section{Method}

\section{Background}

The Preparing for Success at SCU Program (PSP) is an enabling program at Southern Cross University that is 12 weeks in duration, and consists of four subjects. Southern Cross University is a regional university in northern New South Wales, Australia. The program is offered as three sessions a year, and can be studied online or on campus at the institution's campuses in Coffs Harbour, the Gold Coast, and Lismore. The three compulsory subjects equip students with communication, study, and numeracy skills. The fourth subject is an elective, and students can choose between an arts-based or science-based subject. Successful completion of the program provides a distinct pathway into tertiary study at Southern Cross University. The subject EDU10448 Studying Science introduces students to science, and key concepts in biology, physics, and chemistry.

For online students enrolled in the Studying Science subject, weekly online tutorials were held via the Blackboard Learn learning management system (LMS) in a virtual classroom where students and the teacher interacted online during live synchronous sessions. PowerPoint presentations were uploaded and the students and teacher communicated orally and exchanged messages through typing in the chat box, using emoticons, and writing on the shared whiteboard. The online tutorials were recorded and made available to students to watch at a convenient time if they were unable to attend the live online tutorial. The tutorial PowerPoint slides and additional learning resources were available in the Weekly Content folders. In Session 1 
students had access to a study guide in a Portable Document Format (PDF). In Session 2 an interactive online study guide was introduced, but students also had access to the PDF. The interactive study guide consists of reading content, video clips, and interactive activities that are compatible with mobile devices. Students have to log onto to the LMS to access the interactive study guide. The interactive study guide supplements the tutorials. Weekly activities related to the tutorial content were posted on the discussion forum. Students were encouraged to participate on the discussion forum, but it was not mandatory nor graded. Students were also encouraged to ask questions related to the assessments on the discussion forum.

\section{Participants}

Student success, online interaction, and online learner participation of 128 students were examined. Students were enrolled in the online study mode of the Studying Science subject in an enabling program. Sixty-eight students were enrolled in Session 1, 2017, and 60 students were enrolled in Session 2, 2017. Ethics approval was obtained from the Human Research Ethics Committee of Southern Cross University (approval number ECN-16-039).

\section{Procedure}

The data was retrieved from usage information provided by the LMS. Online interaction and online learner participation were measured in terms of quantity. Emails were attained from the teacher and were measured in terms of quantity. Final grades were acquired from the LMS as an indicator for student success. Formal student feedback (anonymous) was acquired from the University's end-of-session feedback reports.

\section{Data analysis}

Descriptive statistics were used to explore the study population's characteristics. Spearman Rank Order Correlation $\left(r_{s}\right)$ analyses were undertaken to examine the associations between final grade and student interaction on the LMS and via email. Mann-Whitney U tests were undertaken to examine differences between students from Session 1 and Session 2. Variables were not normally distributed, thus non-parametric tests were used. Effect size was calculated by $z$ /square root of $n$. The level of significance was set at $p \leq .05$. Statistical analyses were performed using IBM SPSS, Statistics 24 (IBM SPSS; Chicago, Illinois).

\section{Results}

\section{Forms of student interaction}

Student online interaction and online participation are shown in Table 1. Students enrolled in Session 2 had higher (mean) levels of online interaction and participation in all measured areas, except Weekly Content views. Spearman Rank Order Correlational analyses found significant correlations between final grades and the number of views of Assessment details, the number of views of Weekly Content, as well as the number of emails received from students (see Table 2).

A Mann-Whitney U Test found a significant difference in the number of Study Guide views between students enrolled in Session $1(M d=$ $5.00, n=54$ ) and students enrolled in Session 2 $(M d=12.00, n=47), U=727.000, p=.000, r=$ 0.368 . 
Table 1: Students' online interaction and online participation per teaching period

\begin{tabular}{|c|c|c|c|c|c|c|c|c|}
\hline & Session 1 & & & & Session & & & \\
\hline & $\begin{array}{l}\text { Students } \\
(n)\end{array}$ & Total & Range & $M$ & $\begin{array}{l}\text { Students } \\
\text { (n) }\end{array}$ & Total & Range & $M$ \\
\hline $\begin{array}{l}\text { Discussion } \\
\text { forum posts }\end{array}$ & 20 & 79 & $1-22$ & 3.95 & 24 & 111 & $1-24$ & 4.63 \\
\hline $\begin{array}{l}\text { Live Online } \\
\text { Tutorial } \\
\text { attendance }\end{array}$ & 27 & 100 & $1-12$ & 4 & 23 & 120 & $1-12$ & 5 \\
\hline $\begin{array}{l}\text { Assessment } \\
\text { details views }\end{array}$ & 60 & 4014 & $1-198$ & 66.9 & 51 & 3739 & $4-197$ & 73.31 \\
\hline $\begin{array}{l}\text { Study Guide } \\
\text { views }\end{array}$ & 54 & 370 & $1-33$ & 6.85 & 47 & 605 & $3-45$ & 12.87 \\
\hline $\begin{array}{l}\text { Weekly Content } \\
\text { views }\end{array}$ & 55 & 1927 & $1-180$ & 35.04 & 49 & 1684 & $1-148$ & 34.37 \\
\hline $\begin{array}{l}\text { Number of } \\
\text { emails received }\end{array}$ & 39 & 162 & $0-26$ & 2.38 & 40 & 219 & $0-25$ & 3.65 \\
\hline
\end{tabular}

Table 2: Spearman Rank Order correlation between final grades and student activity on the learning management system and the number of emails received from students

\begin{tabular}{|c|c|c|c|c|c|}
\hline & & $\begin{array}{l}\text { Hours on } \\
\text { learning } \\
\text { management } \\
\text { system }\end{array}$ & $\begin{array}{l}\text { Assessment } \\
\text { details } \\
\text { (views) }\end{array}$ & $\begin{array}{l}\text { Weekly content } \\
\text { (views) }\end{array}$ & $\begin{array}{l}\text { Number of } \\
\text { emails } \\
\text { received }\end{array}$ \\
\hline \multirow[t]{3}{*}{ Session 1} & $\begin{array}{l}\text { Final } \\
\text { grade }\end{array}$ & $.762\left(r_{s}\right)$ & $.500\left(r_{s}\right)$ & $.576\left(r_{s}\right)$ & $.293\left(r_{s}\right)$ \\
\hline & & $.000(p)$ & $.000(p)$ & $.000(p)$ & $.030(p)$ \\
\hline & & $55(n)$ & $54(n)$ & $51(n)$ & $55(n)$ \\
\hline \multirow[t]{3}{*}{ Session 2} & $\begin{array}{l}\text { Final } \\
\text { grade }\end{array}$ & $.612\left(r_{s}\right)$ & $.528\left(r_{s}\right)$ & & $.417\left(r_{s}\right)$ \\
\hline & & $.000(p)$ & $.000(p)$ & & $.003(p)$ \\
\hline & & $48(n)$ & $47(n)$ & & $48(n)$ \\
\hline
\end{tabular}


Exploring online interaction and online learner participation in an online science subject through the lens of the interaction equivalence theorem

\section{Quality of learning experience}

The mean final score achieved was 52.96 (i.e. a Pass grade) out of a possible $100(S D=25.92)$ for Session 1. The mean final score achieved was 58.05 (i.e. a Pass grade) out of a possible 100 $(S D=27.41)$ for Session 2. Grades ranged from Fail to High Distinction, as presented in Table 3. Fail grades were awarded to students as a result of non-submission of one or more assessments, or an overall score of less than $50 \%$ for the subject. Absent Fail grades were awarded to students who did not submit any assessments.

Table 3: Sudents' final grade distribution

\begin{tabular}{lll}
\hline \multicolumn{1}{c}{ Final Grade } & $\begin{array}{l}\text { Session 1 } \\
(\boldsymbol{n})\end{array}$ & $\begin{array}{l}\text { Session 2 } \\
(\boldsymbol{n})\end{array}$ \\
\hline Absent Fail & 13 & 12 \\
Fail (0-49\%) & 18 & 13 \\
Pass (50-64\%) & 14 & 6 \\
Credit (65-74\%) & 13 & 15 \\
$\begin{array}{l}\text { Distinction (75-84\%) } \\
\text { High Distinction }\end{array}$ & 10 & 7 \\
$(85-100 \%)$ & 0 & 7 \\
\hline
\end{tabular}

\section{Satisfaction with learning experience}

In Session 1 the Studying Science subject received a score of 4.54 out of 5 for satisfaction with the subject and the teaching and delivery of the subject received a score of 4.38 out of 5 . In Session 2 students rated their satisfaction with the subject at 4.58 out of 5 and the teaching and delivery of the subject was rated 4.47 out of 5. The formal student feedback response rate was 19\% in Session 1 and 32\% in Session 2.

\section{Discussion}

\section{Student-student interaction}

It is generally accepted that online learners need to belong to an interactive community of learners in order to be academically successful (Garrison \& Cleveland-Innes, 2005). However, no significant relationship was found between the number of discussion forum posts made by students and their final grades. Previous research found a relationship between participation in an online discussion forum and academic success (Cheng, Pare, Collimore, \& Joordens, 2011; Davies \& Graff, 2005; Romero, López, Luna, \& Ventura, 2013). However, greater online interaction is not necessarily associated with higher grades (Davies \& Graff, 2005). For example, Cheng et al. (2011) found that there were students who achieved high grades without participating in the discussion forum while other students did poorly although they were actively participating in the discussion forum. Thus, simply increasing the frequency of online participation may not contribute to academic success (Davies \& Graff, 2005). It cannot be assumed that online participation equates to student engagement (Garrison \& Cleveland-Innes, 2005), as online participation can vary from simply accessing the online learning system to taking part in rewarding discussions (Hrastinski, 2008). Garrison and Cleveland-Innes (2005) alleged that interaction is not enough. Students should also explore and critique ideas for deep and meaningful learning. Most of the discussion forum posts in the current study were not discussions between students (i.e. studentstudent interaction) as it consisted of questions related to the assessments and directed towards the teacher. Thus, a simple exchange of information occurred. A previous study found that students who directed questions towards the teacher achieved higher grades (Weisskirch \& Milburn, 2003). 
In the current study the majority of students did not post anything in the discussion forum and it is thus not evident if students engaged in student-student interaction. Online students are often time-poor (Stone, 2017) and have to manage responsibilities such as employment and domestic duties as well as study (Burke, Bennett, Bunn, Stevenson, \& Clegg, 2017; Delahunty et al., 2014). It is possible that students simply do not have enough time to participate in a voluntary unassessed discussion forum. Some students may be cognitively present while not actively participating in the discussion forum (Garrison \& Cleveland-Innes, 2005). They may be participating online by reading messages and learning vicariously. It is thought that online participation is closely related to interaction and is important for building interpersonal connections between students, thus contributing to a sense of community (Delahunty et al., 2014). Students may not perceive online interaction as important as they may not feel the need to belong to an online community (Delahunty et al., 2014) nor value student-student interaction. Students may be focusing on assessments (Owens et al., 2009) instead of building an online community in the time that they have allocated for studying.

\section{Student-teacher interaction}

It appears to make no difference to student success whether students were attending the live online tutorial or watching the recording of the online tutorial. In the current study less than half of the enrolled students attended the live online tutorials, and those students attended on average four of the 12 tutorials in Session 1 and five of the 12 tutorials in Session 2. It is assumed that students watched the recordings of the online tutorials if they were unable to attend the live online tutorial. Unfortunately, the LMS does not capture information regarding 'watching of recordings'. Online tutorials have the ability to enhance the learning experience via studentteacher interaction (Little, Passmore, \& Schullo,
2006; Ng, 2007). On the other hand, the lack of face-to-face contact in online tutorials may reduce students' sense of belonging (McBrien, Jones, \& Cheng, 2009). The relationship between the teacher and students is key to building a sense of belonging to a learning community (Stone, 2017).

Researchers agree that student-teacher interaction is crucial in online learning (Marks, Sibley, \& Arbaugh, 2005; Owens et al., 2009; Stone, 2017). Personalised interactions between teachers and students not only reduce feelings of isolation (McBrien et al., 2009), but are important in learning (Scott, 2008; Trowler, 2010). In the current study the teacher did receive (and replied to) 162 emails from 39 students in Session 1, and 219 emails from 40 students in Session 2. Thus, students did engage in student-teacher interaction. Furthermore, there was a significant relationship between final grades and the number of student emails received by the teacher.

\section{Student-content interaction}

Student-content interaction was evident as demonstrated in Table 2 by the number of times the Weekly Content, study guide, and assessment details were viewed. Studentcontent interaction depends on the extent to which it engages students (Anderson, 2003). Teachers are responsible for providing students with opportunities to attain the necessary academic skills (Taylor, 2013) as well as facilitating student engagement (Trowler, 2010) through active learning and innovative curricula (Scott, 2008). The interface for content delivery is also increasingly important, as many students are using mobile devices for studying (Stone, 2017).

An interactive online study guide was introduced in Session 2. There was a significant difference in the number of times the study guide was accessed between students enrolled in Session 1 and Session 2, with the study guide being accessed more in Session 2. In Session 1 
students had access to a PDF study guide, not an interactive version. In Session 1 the Weekly Content folders were viewed more compared to Session 2. A significant relationship was found between final grades and the number of time the Weekly Content folders were accessed in Session 1.

There was a significant relationship between final grades and the number of times the folders containing assessment details were viewed in the current study. This was not surprising, as final grades are comprised of the assessment scores. Students had to view the assessment details in order to know how to complete assessments. There was a significant relationship between final grades and the number of hours on the LMS in the current study. This is in agreement with other researchers such as Wong (2013), Davies and Graff (2005) who also found that students who spent more time online had higher grades than students who spent less time online. However, Perera and Richardson (2010) found no relationship between academic success and the amount of time spent online. Wong (2013) proposed that there may be a correlation between the amount of time students spent online and the amount of time that they spent studying offline. This may include time working on assessments.

\section{Limitations}

It is acknowledged that the current study had several limitations. The small sample size from a science subject limits the generalisations that can be made from the results obtained. Future studies could collect data from a larger sample of students and other online subjects. In the current study online interaction and online learner participation were measured in terms of quantity rather than the quality of the interaction. It is also possible that students had student-student interaction in one or more of the other online subjects they were enrolled in the PSP, thus eliminating the need for student- student interaction in the Studying Science subject.

Student success is about improving students' academic outcome by increasing student engagement and becoming more effective learners in higher education (Thomas, 2012). Student success is thus a difficult concept to measure, as success can vary for individual students. In the current study student success was measured by final grades. However, it is not known if students felt that learning occurred regardless of the final grade awarded. It was challenging to determine if students had a satisfying educational experience. In the current study a satisfying learning experience was measured by formal student feedback collected at the end of the teaching period. The formal student feedback response rate was $19 \%$ in Session 1 and 32\% in Session 2. Due to the low response rate, it is not known if all students had a satisfying learning experience.

\section{Conclusion}

Anderson (2003) stated that deep and meaningful learning can occur as long as students engage in student-teacher interaction, student-student interaction, or student-content interaction at a high level. If students engage in one of the three forms of interaction at a high level, then the other two forms of interaction are not necessary or can be engaged with at a lower level (Anderson, 2003). The current study provided support for Anderson's interaction equivalency theorem: students did engage in student-teacher interaction and studentcontent interaction while student-student interaction was not evident. It is difficult to tell if 'deep and meaningful learning' occurred, but in the current study it was assumed to be equivalent to student success as measured by the final grade. Furthermore, significant relationships were found between academic success and online learner participation, but not online interaction. Following Anderson's interaction equivalency theorem, it is possible 
to provide students with a satisfying and meaningful learning experience by offering student-student interaction at a minimal or no level. This is in contrast with the generally accepted notion that online learners need to belong to an interactive community of learners in order to be academically successful.

\section{References}

Anderson, T. (2003). Getting the mix right again: An updated and theoretical rationale for interaction. International Review of Research in Open and Distance Learning, 4(2). http://dx.doi.org/10.19173/irrodl.v4i2.149

Aoki, K. (2012). Generations of distance education: Technologies, pedagogies, and organizations. Procedia - Social and Behavioral Sciences, 55(Supplement $\quad$ C), $1183-1187$. https://doi.org/10.1016/j.sbspro.2012.09.613

Australian Council for Educational Research. (2008). Initial educational experiences of tertiary students. LSAY Briefing, 14, 1-8. Retrieved from https://www.lsay.edu.au/ data/assets/pdf file/00 23/181670/LSAY BriefingReport14.pdf

Bernard, R. M., Abrami, P. C., Borokhovski, E., Wade, C. A., Tamim, R. M., Surkes, M. A., \& Bethel, E. C. (2009). A meta-analysis of three types of interaction treatments in distance education. Review of Educational Research, 79(3), 1243-1289. doi:10.3102/003465430933844

Burke, P. J., Bennett, A., Bunn, M., Stevenson, J., \& Clegg, S. (2017). It's about time: Working towards more equitable understandings of the impact of time for students in higher education. Retrieved from National Centre for Student Equity in Higher Education (NCSEHE) website https://www.ncsehe.edu.au/publications/its-abouttime-working-towards-more-equitableunderstandings-of-the-impact-of-time-for-studentsin-higher-education/

Butner, B. K., Smith, A. B., \& Murray, J. (1999). Distance technology: A national study of graduate higher education programs. Online Journal of Distance Learning Administration, 2(3). Retrieved from http://www.westga.edu/ distance/ojdla/

Chapman, E. (2003). Alternative approaches to assessing student engagement rates. Practical Assessment, Research \& Evaluation, 8(13), 1-10. Retrieved from http://pareonline.net/

Cheng, C. K., Pare, D. E., Collimore, L., \& Joordens, S. (2011). Assessing the effectiveness of a voluntary online discussion forum on improving students' course performance. Computers \& Education, 56, 253-261. doi: 10.1016/j.compedu.2010.07.024

Davies, J., \& Graff, M. (2005). Performance in e-learning: Online participation and student grades. British Journal of Educational Technology, 36(4), 657-663. doi:10.1111/j.1467-8535.2005.00542.x

Delahunty, J., Verenika, I., \& Jones, P. (2014). Socioemotional connections: Identity, belonging and learning in online interactions. A literature review. Technology, Pedagogy and Education, 23(2), 243-265. doi: 10.1080/1475939X.2013.813405

Garrison, R., \& Cleveland-Innes, M. (2005). Facilitating cognitive presence in online learning: Interaction is not enough. The American Journal of Distance Education, 19(3), 133-148. https://doi.org/10.1207/s15389286ajde19032

Goertzen, P., \& Kristjánsson, C. (2007). Interpersonal dimensions of community in graduate online learning: Exploring social presence through the lens of Systemic Functional Linguistics. The Internet and Higher Education, 10(3), 212-230. https://doi.org/10.1016/i.iheduc.2007.06.005

Hodges, B., Bedford, T., Hartley, J., Klinger, C., Murray, N., O'Rourke, J., \& Schofield, N. (2013). Enabling retention: Processes and strategies for improving student retention in university-based enabling programs. Final report 2013. Australian Government Office for Learning and Teaching. Retrieved from http://www.enablingeducators.org/resources/CG10 1697 Hodges Report 2013.pdf

Hrastinski, S. (2008). What is online learner participation? A literature review. Computers \& Education, 51, 17551765. doi: 10.1016/j.compedu.2008.05.005

Kahu, E., Stephens, C., Leach, L., \& Zepke, N. (2013). The engagement of mature distance students. Higher Education Research and Development, 32(5), 791-804. doi: 10.1080/07294360.2013.777036

Krause, K.-L., \& Coates, H. (2008). Students' engagement in first-year university. Assessment \& Evaluation in Higher Education, 33(5), 493-505. doi: 10.1080/02602930701698892

Little, B. B., Passmore, D., \& Schullo, S. (2006). Using synchronous software in Web-based nursing courses. CIN: Computers, Informatics, Nursing, 24(6), 317-325. Retrieved from http://journals.lww.com/cinjournal/pages/default.a $\underline{\mathrm{spx}}$

Liu, X., Magjuka, R. J., Bonk, C. J., \& Lee, S. (2007). Does sense of community matters? An examination of participants' perceptions of building learning communities in online courses. Quarterly Review of Distance Education, 8(1), 9-24. Retrieved from http://www.infoagepub.com/quarterly-review-ofdistance-education.html 
Marks, R. B., Sibley, S. D., \& Arbaugh, J. B. (2005). A structural equation model of predictors for effective online learning. Journal of Management Education, 29(4), 531-561. doi:10.1177/1052562904271199

McBrien, J. L., Jones, P., \& Cheng, R. (2009). Virtual spaces: Employing a synchronous online classroom to facilitate student engagement in online learning. International Review of Research in Open and Distance Learning, 10(3), 1-17. Retrieved from http://www.irrodl.org/index.php/irrodl/index

National Centre for Student Equity in Higher Education. (2017). Successful outcomes for regional and remote students in Australian higher education. Retrieved from https://www.ncsehe.edu.au/ncsehe-focussuccessful-outcomes-for-regional-and-remotestudents-in-australian-higher-education/

Nelson, K., Clark, J., Stoodley, I., \& Creagh, T. (2014). Establishing a framework for transforming student engagement, success and retention in higher education institutions. Retrieved from http://studentengagementmaturitymodel.net

$\mathrm{Ng}$, K. C. (2007). Replacing face-to-face tutorials by synchronous online technologies: Challenges and pedagogical implications. International Review of Research in Open and Distance Learning, 8(1). http://dx.doi.org/10.19173/irrodl.v8i1.335

Owens, J., Hardcastle, L., \& Richardson, B. (2009). Learning from a distance: The experience of remote students. Journal of Distance Education, 23(3), 53-74. Retrieved from http://www.ijede.ca/index.php/ide/index

Perera, L., \& Richardson, P. (2010). Students' use of online academic resources within a course web site and its relationship with their course performance: An exploratory study. Accounting Education, 19(6), 587600.

http://dx.doi.org/10.1080/09639284.2010.529639

Pitman, T., Trinidad, S., Devlin, M., Harvey, M., Brett, M., \& McKay, J. (2016). Pathways to higher education: The efficacy of enabling and sub-bachelor pathways for disadvantaged students. Retrieved from National Centre for Student Equity in Higher Education website

https://www.ncsehe.edu.au/publications/pathways -to-higher-education-the-efficacy-of-enabling-andsub-bachelor-pathways-for-disadvantagedstudents/.

Romero, C., López, M., Luna, J., \& Ventura, S. (2013). Predicting students' final performance from participation in on-line discussion forums. Computers \& Education, 68, 458-472. https://doi.org/10.1016/i.compedu.2013.06.009

Sadera, W. A., Robertson, J., Song, L., \& Midon, M. N. (2009). The role of community in online learning success. Journal of Online Learning and Teaching, 5(2), 277-
284.

Retrieved

from

http://jolt.merlot.org/index.html

Scott, G. (2008). University student engagement and satisfaction with learning and teaching. Review of Australian Higher Education request for research and analysis. Department of Education, Employment and Workplace Relations. Retrieved from http://www.voced.edu.au/content/ngv\%3A6058

Stone, C. (2017). Opportunity through online learning: Improving student access, participation and success in higher education. Retrieved from the National Centre for Student Equity in Higher Education website https://www.ncsehe.edu.au/publications/opportuni ty-online-learning-improving-student-accessparticipation-success-higher-education/

Taylor, J. C. (2001). Fifth generation distance education. Instructional Science and Technology, 4(1), 1-14. Retrieved from http://ascilite.org/archivedjournals/e-jist/

Thomas, L. S. (2012). Building student engagement and belonging in higher education at a time of change: Final report from the What Works? Student Retention \& Success programme. Retrieved from https://www.heacademy.ac.uk/resources/detail/wh at-works-studentretention/What works final report

Trowler, V. (2010). Student engagement literature review. Heslington, United Kingdom: The Higher Education Academy. $\quad$ Retrieved from https://www.heacademy.ac.uk/system/files/studen tengagementliteraturereview 1.pdf

Weisskirch, R. S., \& Milburn, S. S. (2003). Virtual discussion: Understanding college students' electronic bulletin board use. The Internet and Higher Education, 6(3), 215-225. https://doi.org/10.1016/S10967516(03)00042-3

Wenger, E. (1998). Communities of practice: Learning, meaning, and identity. Cambridge, United Kingdom: Cambridge University Press.

Wong, L. (2013). Student engagement with online resources and its impact on learning outcomes. Journal of Information Technology Education: Innovations in Practice, 12, 129-146. Retrieved from https://www.learntechlib.org/i/JITE-IIP/

Yorke, M. (2006, July). Student engagement: Deep, surface or strategic? Paper presented at the Pacific Rim First Year in Higher Education Conference, Gold Coast.

Zepke, N. (2013). Student engagement: A complex business supporting the first year experience in tertiary education. The International Journal of the First Year in Higher Education, 4(2), 1-14. doi: 10.5204/intjfyhe.v4i2.183 